\title{
DETERMINANTS OF JAPAN MANUFACTURING EXPORT PERFORMANCE
}

\author{
Rynalto Mukiwihando \\ Jurusan Manajemen Keuangan Politeknik Keuangan Negara STAN \\ email: wihando@pknstan.ac.id
}

\begin{abstract}
:
Export has been believed as an ultimate engine for economic growth. There are many tools to boost export performance. Among of them are foreign networks, $R \& D$ activities and firms' size. A bigger opportunity of overseas market, innovative products and competitive prices are the expected outcome of applying those aforementioned settings within the segmented businesses. This paper aims to obtain empirical insight of the factors that may influence export performance. Employing Japanese manufacturing sector export performance, as one of the leading industries in the world, the study explore the linkage between those three preceding factors to export performance improvement in Japan. Study results shows that research and development activities as well as firm's size play critical roles within the improvement of Japanese manufacturing export performance. Whereas foreign networks, which denoted by foreign subsidiaries, has an insignificant positive contribution to export performance. Future studies may give in-depth focus on the foreign networks issues within a longer period of study. The implication of this study is addressing these two essential issues, $R \& D$ activities and firms' size, to the policy making processes in achieving optimal results of manufacturing export performance.
\end{abstract}

Key Terms: Export, R\&D and Firms' size. 


\section{INTRODUCTION}

In order to grow to be more prosperous, countries have to use their resources, like capital, labor, technology and skills, in the most efficient manner. On the other hand, countries are different in terms of quantity, quality and cost of these resources. The advantages which one particular country may possess are different such as: excellent natural resources, skillful labor, sufficient capital, new innovative ideas and highly developed technology, etc. Rather than trying to produce everything domestically, countries often focus on creating things that they can produce most efficiently. They then trade those for other goods and services. Therefore, both the country and the world become wealthier. The activities usually applied to trade interaction between two countries (international trade) are export and import. Export is defined as selling goods or commodities outside their home countries. Export goods or services are provided to foreign consumers by domestic producers.

International trade has been proposed as a measure to gain an excellent economic growth. There are several reasons behind the notion. Mankiw (2008) assumes that when a country allows trade and becomes an exporter of good, producers of the good are better off, and consumers of the good are worse off. When a country allows trade and becomes an importer of a good, consumers are better off, and producers are worse off. In both cases, the gains from trade exceed the losses.

Studies about the determinants of export performances have been conducted in many aspects. Sjoholm and Takii (2008) by using Indonesian manufacturing data, suggests that plants in Indonesian manufacturing with any foreign ownership are substantially more likely to start exporting than wholly domestically owned plants. In this sense, foreign network is one of the factors affecting export performances in particular countries. By taking advantage of a very complete dataset for Slovenia in the period between 1994 and 2002, Kostevc (2009) test for the effects of foreign market competition on the performance of exporting firms. In addition, by presenting a very basic general equilibrium model and employing fairly general specifications of the demand elasticity function, Kostevc (2009) shows that the model could be used to demonstrate that firms facing intense competition in their export markets have an incentive to improve their efficiency. Ling-yee (2004) concludes that export intensity is driven by the firm's foreign market knowledge and the exporting firms are well advised to build up its background knowledge base, in general, and develop its import/export procedural knowledge in particular. Moreover, Tsai \& Ghoshal (1998) suggests that procedural knowledge provides clear insights on risk, cost, and profit assessment, and the related impact on export performance, this particular kind of knowledge has a direct effect on export profitability.

In another point of view, Madsen and Dilling-Hansen (2002) analyzed the role of research and development (R\&D) in the export behavior of Danish firms. Export behavior is defined as the likelihood of a firm being an exporter. They conclude that $R \& D$ is an important factor for being an exporting firm. This latter finding is also similar with another study by Roper and Love (2001) assumes that for externally-owned plants, in-house $\mathrm{R} \& \mathrm{D}$ is important and for externallyowned plants, R\&D conducted elsewhere in the group-typically outside Irelandproves more significant. Another research by Roper and Love (2001), employing data from UK and German manufacturing plants, implies that product innovation, however measured, has a strong effect on probability and propensity to export in both countries. Being innovative is positively related to export probability in both countries. In the UK the scale of plants' innovation 
activity is also related positively to export propensity. In German, however, where levels of innovation intensity are higher but the proportion of sales attributable to new products is lower, there is some evidence of a negative relationship between the scale of innovation activity and export performance.

Other existing studies also highlight the linkages between firm size and export performance. Ito and Pucik (1993) study results indicate that export sales are positively associated with R\&D expenditures and the size of a firm, and also with the R\&D intensity of the industry. From other different perspectives, firms' $R \& D$ expenditures and asset size are seen as influencing export sales in both subsets of the analyzed firms. In contrast, Bonaccorsi (1992) argues that small firms may succeed in international markets despite their lack of internal specialized resources. The concepts of external resources, least resistance path, collective process and market exit have been proposed as an integration of the current export research. However, Deng, Menguc and Benson (2003) found that human resource management had a substantial impact on enterprise performance as measured by export growth and the percentage of export sales. It is therefore imply that firm size in terms of human resources is playing an important role for company export performances.

Based on preceding studies this paper is aimed to identify any specific factors that contributes to the enhancement of Japanese export performances as a leading country in international trade. Focusing on the manufacturing sector, this study will contribute to the policy improvement to support export activities. Literature and quantitative data analysis studies is implemented in this paper. Models and variable factors such as foreign ownership, trade facilitation and research development investment are mainly refer to existing studies. Therefore, the further implication of this study is proposing the essential agendas in improving export activities in the future.

The paper is organized as follows: section I provides some background introduction, study objectives and research question. Section II describes several theoretical background and existing empirical studies about export performance. Sections III illustrates the recent Japanese export activities and methodology being applied in this study. Lastly, section IV analyzes the empirical results of this study and presents some concluding remarks.

\section{Objectives}

The objective of the study is to examine the factors that influencing Japanese firms' export performances, especially within manufacturing sectors. The importance of the study is to give a valuable perspective for policy maker and other parties involve in improving Japanese export performances in order to create significance contribution to economic development performance within country as a whole.

\section{Research Questions}

By analyzing empirical result of any factors that affecting Japanese manufacturing sector export performances reviewing existing theory and literature studies in this area, this paper aimed to answer these following research questions. First, do foreign networks affect Japanese manufacturing export performance? Another research question is, does research and development activities have an effect on Japanese export performance? And lastly, does firms' size have any linkage to export intensity performance.

\section{Academic Contribution}

Methods originality of this research refer mostly to the international trade theory and many previous empirical studies that have been conducted in this respecting field, especially export performance factors. More details academic contribution presented in this research are elaborated in the following points. 
- This research expands the regression models of export performances by incorporating three independent variables, which are: foreign networks, research and development activities and firms' size.

- This paper focusing on the manufacturing sector, since the field is considered as one of important factor that contributes significantly in economic development particularly in developed countries like Japan.

- The model accommodates practical concept of foreign networks variable which is the number of foreign subsidiaries in specific manufacturing sectors.

- The model also employs different proxy for firms' size that is the number of employment.

- Most likely, this is one of the first of such researches undertaken to study Japanese export performances by addressing foreign networks, research and development activities and firms' size factors.

\section{Relevant Studies}

There have been many studies conducted in investigating the factors that might contribute to the export performance activities. Based on the factors, all the studies can be categorized into 3 different groups. Those factor groups are foreign networks, research and development programs and firm size. Despite some existing research in other perspective such as standard and trade facilitation, still those three previous issues are considered to be the most frequently discussed within any published journals. Moreover, all the studies are still varying in results especially when it comes to specific countries and industries. Therefore, it is important to gain any in-depth knowledge about any factors affected the Japanese manufacturing export performance. All the existing studies include their factors being discussed are can be described in these following classifications.

\section{Export Performance and Foreign Networks}

In focusing on two types of foreign networks: foreign ownership and imports of intermediate products Sjoholm and Takii (2008) conducts study about Indonesian manufacturing export performance. They suggest that plants in Indonesian manufacturing with any foreign ownership are substantially more likely to start exporting than wholly domestically owned plants. In this sense, foreign network is one of the factors affecting export performances in particular countries. Their results remain robust to alternative model specifications and after controlling for other plant characteristics. Additional finding is that there is no effect on exports of imports of intermediate products. Moreover, by taking advantage of a very complete dataset for Slovenia in the period between 1994 and 2002, Kostevc (2009) test for the effects of foreign market competition on the performance of exporting firms. In addition, by presenting a very basic general equilibrium model and employing fairly general specifications of the demand elasticity function, Kostevc shows that the model could be used to demonstrate that firms facing intense competition in their export markets have an incentive to improve their efficiency. Ling-yee (2004) concludes that export intensity is driven by the firm's foreign market knowledge and the exporting firms are well advised to build up its background knowledge base, in general, and develop its import/export procedural knowledge in particular. The study seeks to extend the foreign market knowledge literature in three ways. First, develops a conceptual model of determinants of foreign market knowledge, based on the social capital theory. Second, substantiates the theoretical link between foreign market knowledge and export intensity, which has been put forward by the 
internationalization process model with empirical evidence. Third, to expand the generalizability of the present foreign market knowledge model, this study tests the model using firms from different industrial types and product categories in China. Moreover, Tsai \& Ghoshal (1998) suggests that procedural knowledge provides clear insights on risk, cost, and profit assessment, and the related impact on export performance, this particular kind of knowledge has a direct effect on export profitability. Pfaffermayr (2004), using data on Austrian manufacturing firms, analyzes the impact of the propensity to export and the existence of foreign affiliates on the growth performance of firms at their domestic location. The results from dynamic panel regressions do not suggest that foreign affiliate activity exerts negative effects on the expansion of domestic activities. Furthermore, foreign affiliate activity seems to preserve and even reinforce a firm's growth potential at its domestic location

\section{Export Performance and R\&D activities}

The studies about the relationship between $R \& D$ activities and export performance are also conducted in several ways. Madsen and DillingHansen (2002) analyzed the role of research and development (R\&D) in the export behavior of Danish firms. Export behavior is defined as the likelihood of a firm being an exporter. In the theoretical part of the paper it is argued that export and being $\mathrm{R} \& \mathrm{D}$ active are endogenous with respect to each other, and an empirical model is formulated in order to estimate which factors affect the firm's export. It is argued that besides $\mathrm{R} \& \mathrm{D}$, firm size, wages and a number of other firm-specific factors controlling for risks are highly important for the export performance. In the empirical part of the paper the model is tested on a sample of 3,500 Danish firms. Using a FIML estimation form in order to deal with endogeneity problems between the R\&D and export decisions of the firms, the computation clearly verifies the theoretical model put forward. They conclude that $\mathrm{R} \& \mathrm{D}$ is an important factor for being an exporting firm. This latter finding is also similar with another study by Roper and Love (2001) assumes that for externally-owned plants, in-house $\mathrm{R} \& \mathrm{D}$ is important and for externallyowned plants, R\&D conducted elsewhere in the group-typically outside Irelandproves more significant. Another research by Roper and Love (2001), employing data from UK and German manufacturing plants, implies that product innovation, however measured, has a strong effect on probability and propensity to export in both countries. Being innovative is positively related to export probability in both countries. In the UK the scale of plants' innovation activity is also related positively to export propensity. In German, however, where levels of innovation intensity are higher but the proportion of sales attributable to new products is lower, there is some evidence of a negative relationship between the scale of innovation activity and export performance. Guan and $\mathrm{Ma}$ (2002), employing 213 Chinese industrial firms as their sample, assumes that export growth is closely related to the total improvement of innovation capability dimensions, except for the manufacturing capability. In addition, they argue that core innovation assets (a set of R\&D, manufacturing and marketing) alone cannot lead to sustainable export growth and implies the interaction and harmonizing of various innovation assets are the primary factors in the improvement of international competitiveness of Chinese firms. Ito and Pucik (1993) examine three factors influencing the export performances of Japanese manufacturing firms: $R \& D$ spending, domestic competitive position, and firm size. Export sales are positively associated with (1) R\&D expenditures, (2) size of a firm, and (3) average $R \& D$ intensity of an industry. A firm's export ratio is related to the size of the firm, but not to the firm's and the industry's R\&D 
intensities. The results indicate a relationship between the patterns of domestic competition and the international competitiveness of Japanese firms. Tomiura (2007) examines how internal $\mathrm{R} \& \mathrm{D}$ intensity and external networking channels are related with the firm's export decision, based on a large firm-level data set covering all manufacturing industries in Japan without any firm-size threshold. Internal $R \& D$ is not the only determinant of exporting, while it is strongly related with exports in the science-based sector. Collaborations with other firms on joint projects and operations of subsidiaries overseas are significantly linked to exports of large-sized firms, while affiliations with business associations and $R \& D$ intensity are critical for small-sized firms to export.

\section{Export Performance and Firms' size}

Guan and Ma (2002) suggests although the larger firms demonstrate stronger export competitiveness, there has been no finding of an inverted Ushaped relationship between export and firm size.Ito and Pucik (1993) study results indicate that export sales are positively associated with $R \& D$ expenditures and the size of a firm, and also with the $R \& D$ intensity of the industry. From other different perspectives, firms' $R \& D$ expenditures and asset size are seen as influencing export sales in both subsets of the analyzed firms. In contrast, Bonaccorsi (1992) argues that small firms may succeed in international markets despite their lack of internal specialized resources. The concepts of external resources, least resistance path, collective process and market exit have been proposed as an integration of the current export research. The aforementioned results may contradicts with existing export marketing literature such argument in international marketing economies of scale, limited managerial and financial resources of small firms, decision maker's risk perception. Based on a large survey of the Italian manufacturing industry, the article falsifies the proposition and challenges some widely held assumptions in export marketing literature. However, Deng, Menguc and Benson (2003) found that human resource management had a substantial impact on enterprise performance as measured by export growth and the percentage of export sales. It is therefore imply that firm size in terms of human resources is playing an important role for company export performances. Baldauf, Cravens and Wagner (2000) mention that in addition to firm size, the most promising predictors of export performance are management's motives to internationalize and the use of a differentiation strategy. These findings are important because the latter two dimensions are management decision variables. The results of the study are relevant for managers operating in small open economies whose companies must consider both domestic and international developments.

\section{METHOD}

In this section, several theoretical backgrounds is provided to support a strong foundation of the study and by which leads the overall study to the right and proper direction.

\section{Theoretical Background}

Mankiw $(2008,56)$ illustrates the principle of comparative advantage shows that trade can make everyone better off. In addition, in terms of international trade, Mankiw (2008,177 and 179) assumes that when a country allows trade and becomes an exporter of good, producers of the good are better off, and consumers of the good are worse off. When a country allows trade and becomes an importer of a good, consumers are better off, and producers are worse off. In both cases, the gains from trade exceed the losses.

Mankiw $(2008,57)$ also suggests some other benefits of international trade which include export and import businesses, which are: 
- Increased variety of goods

Goods produced in different countries are not exactly the same. Free trade gives consumers in all countries greater variety from which to choose.

- Lower costs through economies of scale

Some goods can be produced at low cost only if they produced in large quantities (a phenomenon called economies of scale). A firm in a small country cannot take full advantage of economies of scale if it can sell only in a small domestic market. Free trade gives firms access to larger world markets and allows them to realize economies of scale more fully.

- Increased competition

A company shielded from foreign competitors is more likely to have market power, which in turn gives it the ability to raise prices above competition levels. This is a type of market failure. Opening up trade fosters competition and gives the invisible hand a better chance to work its magic.

- Enhanced flow of ideas

The transfer of technological advances around the world is often thought to be linked to the trading of the goods that embody those advances. The best way for a poor agricultural nation to learn about computer revolution, for instance, is to buy some computers from abroad rather than trying to make them domestically.

\section{Japanese Manufacturing Export Performance}

The most extraordinary phenomena of Japan's economic growth performance, after World War II is the rapid development of manufacturing sectors, with special emphasize on its improvement in productivity and efficiency. This feature is achieved by implementing magnificent development in technological sides, it can be looked from several successful Japanese manufacturing products which are very diversified and embodied with a variety of advanced industries. Therefore, the role of research and development activities is undeniable within this achievement.

Furthermore, at least there are two distinguished features of the post-war economy of Japan. The first is its close interlocking structures of manufacturers, suppliers, and distributors, known as keiretsu. Secondly, Japanese manufacturer implements lifetime employment system. Inevitably, human resources are the important in expanding Japanese manufacturing performance.

Japanese manufacture sector is heavily dependant from imported raw material from. Moreover, this sector also faced by possibility of market shrinking from overseas market, due to many in conducive situations such as protectionism action by influential importing countries. Thus, having foreign networks is totally a good way of solution in maintaining export market especially for manufacturing sector. Several stages have been taken including establishing foreign subsidiaries and foreign direct investment as well.

\section{Japanese Manufacturing Export Performance by sector}

Chart 1

Japanese Manufacturing Export Performance by sector

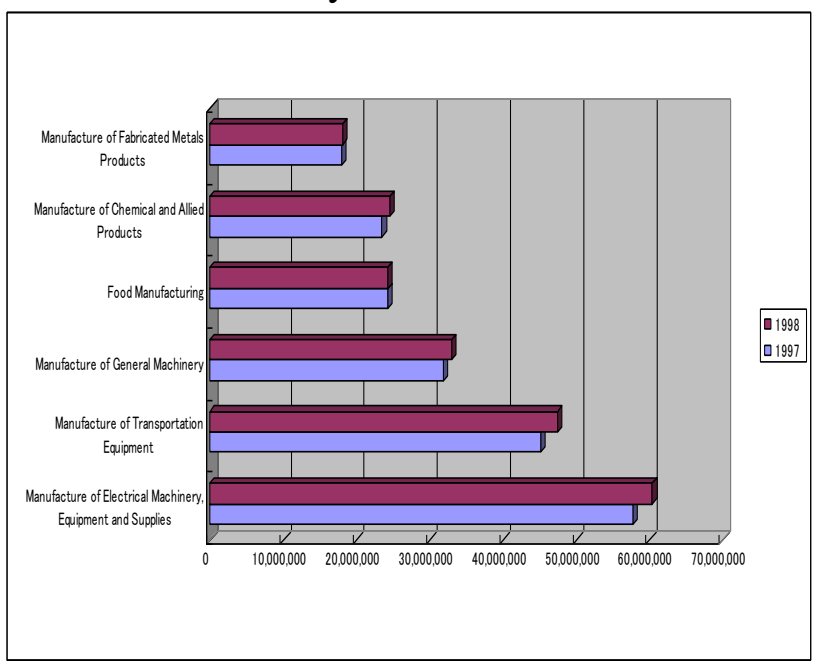

Source: Statistics on Japanese Industries, 1998 and 1999, Research and Statistics Dept of METI 
Based on charts above, the top six of manufacturing export performance by sector are electrical machinery, transportation equipment, general machinery, food manufacturing, chemical and allied products and fabricated metal products. It is imply that the biggest Japanese manufacturing sector export share is electrical machinery. The number is approximately $\mathbf{5 7 . 7 4 7 . 7 8 6}$ and 60.381.351 for the year of 1997 and 1998.

\section{Japanese Manufacturing Export \\ Performance by prefecture} Chart 2

Japanese Manufacturing Export Performance by prefecture

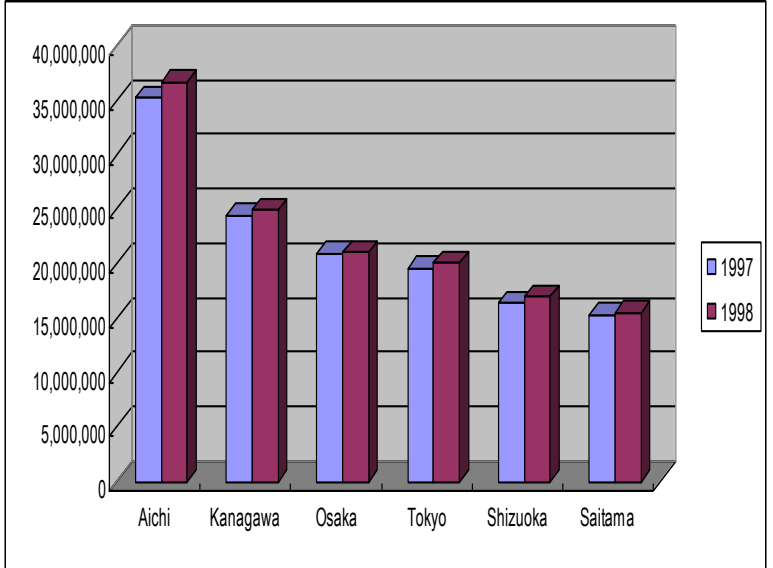

Source: Statistics on Japanese Industries, 1998 and 1999, Research and Statistics Dept of METI

Refer to preceding figures, the top five manufacturing export performance by prefecture are Aichi, Kanagawa, Osaka Tokyo and Shizuoka. It is shown that the highest Japanese manufacturing sector export share comes from Aichi prefecture, which sells manufacturing up to 35.234 .561 and 36.659 .520 for two consecutive years 1997 and 1998.

\section{Data Unit}

The data sample being used in this study is the 22 Japanese manufacturing sectors which is being classified according to Statistics on Japanese Industries, 1998 and 1999, from Research and Statistics Department of METI. Cross section data being employed in this paper are mostly from 1997 performance except for research and development expense and the number foreign subsidiaries which originated from one year before. All the Japanese manufacturing categories are:

Table 1

Manufacturing Sectors

\begin{tabular}{|c|l|}
\hline No & \multicolumn{1}{|c|}{ Manufacturing sectors } \\
\hline 1 & Food Manufacturing \\
\hline 2 & $\begin{array}{l}\text { Manufacture of Beverage, Feed and } \\
\text { Tobacco }\end{array}$ \\
\hline 3 & $\begin{array}{l}\text { Manufacture of Textile Mill Products, } \\
\text { Except Apparel and Other finished } \\
\text { products }\end{array}$ \\
\hline 4 & $\begin{array}{l}\text { Manufacture of Apparel and Other } \\
\text { finished Made Fabrics and similar } \\
\text { materials }\end{array}$ \\
\hline 5 & $\begin{array}{l}\text { Manufacture of Lumber, and Wood } \\
\text { Products, Except Furniture }\end{array}$ \\
\hline 6 & Manufacture of Furniture and Fixtures \\
\hline 7 & $\begin{array}{l}\text { Manufacture of Pulp, Paper and Paper } \\
\text { Products }\end{array}$ \\
\hline 8 & Publishing, Printing and Allied Products \\
\hline 9 & $\begin{array}{l}\text { Manufacture of Chemical and Allied } \\
\text { Products }\end{array}$ \\
\hline 10 & $\begin{array}{l}\text { Manufacture of Petroleum and Coal } \\
\text { Products }\end{array}$ \\
\hline 11 & $\begin{array}{l}\text { Manufacture of Plastic Products, not } \\
\text { elsewhere classified }\end{array}$ \\
\hline 12 & Manufacture of Rubber Products \\
\hline 13 & $\begin{array}{l}\text { Leather Tanning and Manufacture of } \\
\text { Leather Products, and Fur Skins }\end{array}$ \\
\hline 14 & $\begin{array}{l}\text { Manufacture of Ceramic, Stone and Clay } \\
\text { Products }\end{array}$ \\
\hline 15 & Iron and Steel Industry \\
\hline 16 & $\begin{array}{l}\text { Manufacture of Non-Ferrous Metals and } \\
\text { Products }\end{array}$ \\
\hline 17 & $\begin{array}{l}\text { Manufacture of Fabricated Metals } \\
\text { Products }\end{array}$ \\
\hline 18 & Manufacture of General Machinery \\
\hline 19 & $\begin{array}{l}\text { Manufacture of Electrical Machinery, } \\
\text { Equipment and Supplies }\end{array}$ \\
\hline 20 & $\begin{array}{l}\text { Manufacture of Transportation } \\
\text { Equipment }\end{array}$ \\
\hline 21 & $\begin{array}{l}\text { Manufacture of Precision Instrument and } \\
\text { Machinery }\end{array}$ \\
\hline 22 & Miscellaneous Manufacturing Industries \\
\hline
\end{tabular}

\section{Data sources}

All the data sources were taken from Statistics on Japanese Industries publication in 1998 and 1999, by Research and Statistics Department of Ministry of Economy, Trade 
and Industry (METI). All the categories taken can be described as follows:

Table 2

Data Categories

\begin{tabular}{|c|l|}
\hline No & \multicolumn{1}{|c|}{ Categories } \\
\hline 1 & $\begin{array}{l}\text { Value of shipments (in million } \\
\text { yen) }\end{array}$ \\
\hline 2 & $\begin{array}{l}\text { The number of foreign } \\
\text { subsidiaries }\end{array}$ \\
\hline 3 & $\begin{array}{l}\text { Research and development } \\
\text { expenses ((in million yen) }\end{array}$ \\
\hline 4 & $\begin{array}{l}\text { The number of employees } \\
\text { (only for establishments with } 4 \\
\text { or more employees) }\end{array}$ \\
\hline
\end{tabular}

Data variables

All the data variables along with their abbreviation applied in this study can be explained as follows:

Table 3

Data Variables

\begin{tabular}{|c|l|c|}
\hline No & \multicolumn{1}{|c|}{ Categories } & sign \\
\hline 1 & $\begin{array}{l}\text { Value of shipments (in } \\
\text { million yen) }\end{array}$ & exp \\
\hline 2 & $\begin{array}{l}\text { The number of foreign } \\
\text { subsidiaries }\end{array}$ & fore \\
\hline 3 & $\begin{array}{l}\text { Research and } \\
\text { development expenses } \\
\text { ((in million yen) }\end{array}$ & $r d$ \\
\hline 4 & The number of employees & employ \\
\hline
\end{tabular}

\section{Econometric Model}

The paper employs this following crosssection econometric equation:

$$
Y=\beta_{0}+\beta_{1} X_{1}+\beta_{2} X_{2}+\beta_{3} X_{3}+\mu_{1}
$$

Based on the model above the variable dependent $(\mathrm{Y})$ is export performance proxied by value of shipment. While, for the independent variables are the number of foreign subsidiaries that denotes foreign networks $\left(\mathrm{X}_{1}\right)$, research and development expenses(R\&D) $\left(\mathrm{X}_{2}\right)$ and firms' size represented by the number of employee $\left(\mathrm{X}_{3}\right)$. All the data are come from 1997 statistic numbers, except for $\mathrm{X}_{1}$ and $\mathrm{X}_{2}$. This paper argues that both $\mathrm{R} \& \mathrm{D}$ expenses and foreign subsidiaries do not have immediate direct effect on company export performance in the same year, Therefore in this study one year before (1996) data was taken in order to accommodate the issue.

\section{RESULT AND DISCUSSION}

\section{Result}

The analysis method is quantitative data analysis using STATA statistical tools. Results obtained from STATA can be described as follows:

. reg exp fore rd employ

$\begin{array}{ll}\text { Source } & \text { SS } \\ \text { Number of obs }= & \text { MS }\end{array}$

$\mathrm{F}(3,18)=239.10$

Model| 4.3042e+15 $3 \quad 1.4347 \mathrm{e}+15$

Prob > F $=0.0000$

Residual | $1.0801 \mathrm{e}+14 \quad 18 \quad 6.0005 \mathrm{e}+12$

$\mathrm{R}$-squared $=0.9755$

Adj R-squared $=0.9714$

\begin{tabular}{l|lll} 
Total & $4.4122 \mathrm{e}+15$ & 21 & $2.1011 \mathrm{e}+14$
\end{tabular}

Root MSE $=2.4 \mathrm{e}+06$

$\exp \mid$ Coef. Std. Err. $\mathrm{t} \quad \mathrm{P}>|\mathrm{t}|$ [95\% Conf. Interval]

\begin{tabular}{|c|c|}
\hline fore | $1843.981 \quad 2229.545$ & 0.83 \\
\hline $\begin{array}{lll}0.419 & -2840.119 & 6528.082\end{array}$ & \\
\hline rd | $7811.237 \quad 1121.094$ & 6.97 \\
\hline $\begin{array}{lll}0.000 & 5455.905 & 10166.57\end{array}$ & \\
\hline employ | 21.602912 .313244 & 9.34 \\
\hline $\begin{array}{lll}0.000 & 16.74297 & 26.46286\end{array}$ & \\
\hline _cons $\mid \begin{array}{lll}-2264730 & 958982.6\end{array}$ & -2.36 \\
\hline $\begin{array}{lll}0.030 & -4279477 & -249981.9\end{array}$ & \\
\hline
\end{tabular}

STATA results can also be explained in the following table: 
Table 4

Statistical Results

\begin{tabular}{|c|l|c|}
\hline No & \multicolumn{1}{|c|}{ Variables } & Results \\
\hline 1 & Fore & 1843.981 \\
& ign subsidiaries & $(2229.545)$ \\
\hline 2 & R\&D Expenses & $7811.237^{*}$ \\
& & $(1121.094)$ \\
\hline 3 & Number of & $21.60291^{*}$ \\
& employments & $(2.313244)$ \\
\hline \multicolumn{2}{|c|}{$*$ significant at 1\% level }
\end{tabular}

\section{Discussion}

After running the data by STATA program, there are several findings of the test to be discussed:

- First variable which is foreign networks that denoted by foreign subsidiaries has insignificant positive effects. It is conclude that although foreign networks may contribute to the export performance, but still the effect is not significant.

- Research and development activities which represented by $R \& D$ expenses from the previous year has positive and significant efffect to the japanese manufacturing export performance. However, the impact of $R \& D$ activities is observed in the next following year as being discussed in the model.

- The coefficient of number of employees demonstrates that firms' size play important role in terms affecting Japanese manufacture export performance. In fact, the $t$ statistics of the number of employees the highest compare to the other two variables. Hence, it may need further consideration for related parties in formulating policy that aimed to improving Japanese manufacturing export performance.

- From the model, R square number very high, which is .97 , it implies that the model explains $97 \%$ relationship between independent variables and dependent one. The $\mathrm{R}$ square percentage exhibits that foreign network, R\&D activities and Firms' size are the 3 main factors that significantly impact Japanese manufacturing export performance.

\section{$\underline{\text { CONCLUSION }}$}

Consistent with existing theory and several empirical evidences, this study results also confirm the positive and contribution of research and development activities as well as firms' size to export performance. This empirical results support the concept of innovation that leads a greater market. Innovation produced by having $R \& D$ activities within businesses cycle. On the other hand, firms size denoted by the number of employee is inherent with the theory growth which originated from one of the three factors; capital, labor and technology. It is essential to maintaining the employment rate for reaching Japanese manufacture economies of scale in the future. This reality may drives all the authorized institutions to keep the pace of development in these respective fields so that later on it will create improvement in Japanese manufacturing export performance. Contrary to that, the important finding of the study is that foreign networks variable does not play a significant role in improving Japanese export performances. Although it gives positive effect on export performance, still this factor needs some period of time to grow to support Japanese manufacturing export performance in the next following years.

This study comprises several limitations that need to be a concern in the next future studies. Cross section analysis used in this study may be accompanied by time series or panel data analysis which can provide more comprehensive in understanding of the determinant factors of Japanese export performance. The symbolization of the number of foreign subsidiaries may not offer complete and representatives approaches as a proxy for foreign networks. Therefore, employing other 
measurement may give other different result. Lastly, due to availability of data, this paper only addressing year 1997 as a study period, as a consequence the outcome may being disturbed by the Asian economic crisis during 1997 and 1998 periods.

\section{REFERENCES}

Baldauf, Artur, David W Cravens, and Udo Wagner. (2000), Examining Determinants of Export Performance in Small Open Economies, Journal of World Business 35 (1): 61-79.

Bonaccorsi, Andrea (1992), On the Relationship between Firm Size and Export Intensity, Journal of International Business Studies, Vol. 23, No. 4 (4th Qtr., 1992), pp. 605-635

Deng, J, Menguc, B. and Benson, J. (2003), The Impact of Human Resource Management on Export Performance of Chinese Manufacturing Enterprises, Thunderbird International Business Review, 45: 409-29.

Guan, J and Ma, N (2002) Innovative capability and export performance of Chinese firms Technovation 23 (2003) 737-747

Ito, Kiyohiko and Pucik, Vladimir (1993), R\&D Spending, Domestic Competition, and Export Performance of Japanese Manufacturing Firms Strategic Management Journal, Vol. 14, No. 1 (Jan., 1993), pp. 61-75

Kostevc (2009) Foreign Market Competition as a Determinant of Exporter Performance: Evidence from Slovenian Manufacturing Firms, The World Economy (2009)

Ling-yee, Li, (2004), An examination of the foreign market knowledge of exporting firms based in the People's Republic of China: Its determinants and effect on export intensity, Industrial Marketing Management 33 (2004) 561- 572

Mankiw, N, Gregory, (2008), Essentials of Economics 5th edition, South Western 2008;

Pfaffermayr, Michael (2004), Export orientation, foreign affiliates, and the growth of Austrian manufacturing firms, Journal of Economic Behavior \& Organization Vol. 54 (2004) 411-423

Roper Stephen and Love James H (2001), Innovation and export performance: evidence from the UK and German manufacturing plants, Research Policy 31 (2002) 1087-1102

Sjoholm, Fredrik and Takii, Sadayuki, (2008), Foreign Networks and Exports: Results from Indonesian Panel Data, The Developing Economics, XLVI-4, 42846;

Smith, V., Madsen, E., and Dilling-Hansen, M. (2002) Do R\&D investments affect export performance? WP 2002/4, The Danish Institute for Studies in Research and Research Policy, Aarhus.

Tomiura, Eiichi, (2007), Effects of R\&D and networking on the export decision of Japanese firms, Research Policy 36 (2007) 758-767; 


\section{Notes}

\begin{tabular}{|l|l|l|}
\hline 1. & Chart 1 & $\begin{array}{l}\text { Japanese Manufacturing } \\
\text { Export Performance by } \\
\text { sector }\end{array}$ \\
\hline 2 & Chart 2 & $\begin{array}{l}\text { Japanese Manufacturing } \\
\text { Export Performance by } \\
\text { prefecture }\end{array}$ \\
\hline 3 & Table 1 & Manufacturing Sectors \\
\hline 4. & Table 2 & Data Categories \\
\hline 5 & Table 3 & Data Variables \\
\hline 6 & Table 4 & Statistical Results \\
\hline
\end{tabular}

